\title{
An Investigation into the Implications of Islamic Work Ethic (IWE) in the Workplace
}

\author{
*Salih Yesil, Zumrut Hatice Sekkeli, Ozkan Dogan \\ Kahramanmaraş Sütçü İmam Üniversity, Kahramanmaraş, Turkey \\ *syes66@hotmail.com
}

\begin{abstract}
There has been an increasing interest on the work ethics and its various aspects among the academicians and practitioners. This is partly because of the ethical scandals that have occurred in the recent years and got attention from media and public and therefore raised the questions regarding ethical standards of companies and its practical use in the business life. This interest has prompted several research into the topic both theoretical and practical levels. Although the studies have accumulated in the Western World, the studies coming from the developing countries are limited and thus call for the studies to further investigate the dynamics and implications of the work ethics. This study particularly pays attention to Islamic work ethic and aims to identify whether Islamic work ethic values differ across various demographic variables and firm characteristics. The study also investigates the relationship between the Islamic work ethic and innovation capability and firm performance. The study is supported with a field study conducted on the firms operating in Kahramanmaraș in Turkey. The obtained data was analyzed by using Correlation, ANOVA, T-test and Regression in SPSS. The results showed that IWE values differ across some characteristic of the respondents and firms. The results also indicate the positive influence of IWE values on innovation capability and firm performance.
\end{abstract}

Keywords: Work Ethic, Islamic Work Ethic, Demographic Characteristics, Firm Characteristics, Innovation Capability, Firm Performance

\section{Introduction}

Ethic has been one of the most widely discussed and researched topic in the recent years. Quddus et al., (2009) noted that there is an increasing emphasis in business ethics and teaching and learning of the ethics. Similarly Jalil et al., (2010) argued that ethic and ethical behaviour are in the centre of arguments in business community worldwide. The interest in business ethic come from the fact that recent years has witnessed several scandals that are attributed to the lack of or insufficient ethical standards in business community (Hodgetts and Luthans, 2000; Rokhman, 2010). Practicing ethic at organizational level creates a number of benefits to the organizations and this in turn creates an interest in work ethics. Jalil et al. (2010) argued that ethical practices could help organization to create good relationship with other organizations and long-term relationship with future potential customers. The worldwide ethical scandals and increasing the importance and advantages of work ethics in the workplace have stimulated work ethic research across the world (Rokhman, 2010). Yet, the studies regarding the work ethic mainly come from USA and Europe (Ahmad, 2011; Kumar and Rose, 2010; Rokhman, 2010). Relatively few studies are conducted in developing countries and thus further research is needed. In addition to the insufficient work ethic studies in developing countries, research regarding Islamic work ethic (IWE) and its implications in the workplace are limited (Ahmad, 2011; Kumar and Rose, 2010; Rokhman, 2010). Previous studies have looked at the role of Islamic work ethic on mainly HRM practices, work and individual related outcomes such as change, commitment, job satisfaction and turnover (Haroon et al. 2012; Mohamed et al. 2010; Rahman et al. 2006; Rokhman, 2010; Yousef, 2001), innovation (Abbasi et al. 2012; Awan and Akram, 2012; Kumar and Rose, 2010) and firm performance (Abbasi et al. 2012). Some studies were also dedicated to scale development (Ali, 1988) as well as literature review (Ahmad, 2011; Ali and Al-Owaihan, 2008). Considering the lack of work ethic studies in developing countries as well as limited number of studies related to IWE constitute the foundation to investigate the implications of IWE in the workplace. Moreover, the implication of IWE on innovation capability and firm performance has not received much attention from the researchers (except the studies of Awan and Akram, 2012 and Kumar and Rose, 2010). Uygur (2009) also calls for empirical research regarding IWE in Turkey. Therefore, this study is undertaken to investigate the role of the IWE on firm innovation capability and performance. Considering the importance of innovation and innovation capability for the success of the organisations (Calantone et al. 2002: Lawson and Samson, 2001), this study is likely to bring new insight into the determinants of innovation capability and performance in organisations. The current study looks 
at whether the IWE values differ across the various demographic variables of respondent and company characteristics and investigate the role of IWE values on innovation capability and firm performance. The study is supported with an empirical study conducted in Kahramanmaraş in Turkey. Target population of this study is the managers in the company's operating within the district of this city. The result of this study is also expected to give valuable information regarding the implications of IWE values in the workplace as well as understanding the factors that improve innovation capability and firm performance.

\section{Literature Review}

Business (Work) Ethic: Mendenhall et al. (1995) argued that virtually all societies have developed rules and regulations about business transaction and management of the business organizations. In other words, based on the experience and the philosophical and/or religious values of a society, rules of acceptable and no acceptable behaviors evolve and are encoded into society. Arnold et al. (2010) stated that "business ethic as an academic discipline originated in the mid-1970s in response to ethical lapses in the practice of business. Further development with regard to work ethic came after this date including conferences, books and teaching in the schools". Ip (2010) noted that there are two dimensions to business ethic: empirical business ethic and normative business ethic. Empirical business ethic concerns how business actually treats its stakeholders ethically. Normative business ethic focus on how business ought to be conducted ethically with respect to its stakeholders. Business ethic has been defined in various ways in the literature. Maddux et al. (1989) defines business ethics as being fully aware of what we are doing, including the consequences and complications of our actions. Parker (1998) explained, "Business ethics attempts to recognize the relationship of acts to the good of the individual, the firm, the business community and society". Ip (2010:97) defines work ethic as "the way business practices its ethic in a country. Work ethic involves the complicated processes and relationship business has with its stakeholders and the environment. How corporations deal ethically with their stakeholder, employees, customer, communities, society and the environment, among the others, constitute the major concern of business ethic". According to Porter (2010), work ethic is "the manifestation of personally held values". A recent survey (Deloitte, 2010) conducted on ethic reveals the diminishing value of work ethic in the workplace affected by the recent recession. Business ethic is an important concept because ethical considerations affect the business organizations of all sizes as they affect all form of human activity (Jalil, 2010). Work ethic is also important for economic development and success of the countries (Jalil, 2010). Porter (2010) places work ethic an important factor behind the success of USA. Previous research on work ethic has been conducted mainly in the USA and Europe, the lack of studies in developing countries is evident in the literature (Ahmad, 2011; Kumar and Rose, 2010; Rokhman, 2010). Previous studies tend to relate work ethic to the several individual (e.g., Koonmee et al. 2009; Mortensen et al. 1989; Sabir et al. 2012; Sparrow et al. 2010) and organizational outcomes (e.g., Berrone et al. 2007; Donker et al. 2008; Sabir et al. 2012) in the workplace. For instance, Sparrow et al. (2010) found that the work ethic is positively related to organizational citizenship behavior. Koonmee et al. (2009) found that implicit ethics institutionalization but not explicit institutionalization is positively related to job satisfaction. They found no effect of explicit ethic institutionalization on the same outcomes. In a different study, Berrone et al. (2007) reported the indirect effect of firm ethical behaviors on financial performance through stakeholder satisfaction. Mortensen et al. (1989) found the importance of ethic for the job performance. Sabir et al. (2012) found that ethical values are positively related to ethical leadership and employee performance. Doker et al. (2008) found that corporate ethical values are positively correlated with firm performance.

Islamic Work Ethic: Porter (2010) argued that every culture has unique history and set of conditions that influence the meanings given to work in people's life. Culture along with religious background has an impact on the people's ethical thought and behaviors. Quddus et al. (2009) noted that religious background and beliefs affect ethics and ethical understanding of people. Thus, people reflect their religious thought and beliefs in understanding and practicing ethic in daily and business life. The IWE has its origin in the Quran and the sayings and practice of the Prophet Mohammed (Ali and Al-Owaihan 2008: Rice, 1999). The IWE includes economic, social and moral dimensions (Ahmad, 2011). Jalil (2010) noted, "Ethic can be understood in Islamic terms as haya, the state of respect and the practice of good deeds. Muslim should reflect the Islamic ethic in all parts of his or her life including business life". Ali and AlOwaihan (2008) explained, "The IWE is an orientation that shapes and influences the involvement and participation of believers in the workplace". Ethic in business from Islamic point of view implies honesty, trust and a relationship between employers and employees that reflects the fact that they are part of the 
same brotherhood or sisterhood and spiritually equal before God, even if not materially equal on earth (Bassiouni, 1993, cited in Wilson, 2006). Kumar and Rose (2010) explained the four principles of IWE values referring to Ali (2005). These principles: effort, competition, transparency and morally responsible conduct. These principles collectively inspire social contract and encourage a better focus on meeting organizational task (Ali, 2005). The IWE has been subject of many theoretical as well empirical studies from various perspectives. Previous studies on IWE have looked at the role of IWE on mainly HRM practices and work and individual related outcomes such as commitment, satisfaction and turnover (Rahman et al. 2006; Rokhman, 2010; Othman et al. 2004; Yousef, 2001). For instance, Rokhman (2010) found that IWE is positively related to both job satisfaction and organizational commitment. The results revealed that there was no significant relationship between IWE and turnover intention. Alhyasat (2012) found that while some dimensions of IWE (kindness and forgiveness in dealing with employees and clients, obedience to the people in power and respecting job ethics) were associated with organizational citizenship behaviour among employees, others (proficiency, giving advice to Muslims, sense of responsibility, justice and fairness, integrity and teamwork) had no significant effect on organizational citizenship behaviour. Yousef (2001) reported that IWE is positively related to commitment and employee attitude toward change. On the other hand, commitment mediates the relationship between IWE and employee attitude toward change. According to the result of Haroon et al. (2012)' study, IWE is positively related to the job satisfaction of nurses working in private hospitals. Another study reports the positive relationship between Islamic management ethic and commitment (Salem and Agil, 2012). In relation to the current study, Kumar and Rose (2010) found that the IWE measure is positively correlated with innovation capability. Abbasi et al. (2012) reported the positive effect of IWE on learning, innovation and organizational performance. In a study conducted on public sector organisations, Awan and Akram (2012) reported that that IWE has a significant positive effect on innovation capability and additionally knowledge sharing mediates this relationship. Considering the relatively few studies regarding the implications of IWE on individual and organisational process and outcomes, the current study is expected to make important contribution to the literatures under study.

Innovation and Innovation Capability: Innovation is mostly regarded as essential to the success of organizations of all types (Calantone et al. 2002: Günday et al. 2009; Knight and Cavusgil, 2004). Van De Ven (1986) defined innovation as "the development and implementation of new ideas by people who over time engage in transaction within an institutional order". This definition focuses on four basic factors (new ideas, people, transactions and institutional context). Innovation refers to the generation, acceptance, and implementation of new ideas, processes, products, or services (Calantone et al. 2002). Oslo Manual (2005) defines innovation as "the implementation of a new and significantly improved product (good or service), or a process, a new marketing method, or a new organizational method in business practice, workplace organizations or external relations". Calantone et al. (2002) argued that Drucker (1954) was the first scholars to address the importance of innovation capability for organization. Drucker suggests that a firm has to be innovative to survive in the volatile environment. Innovation capabilities are critical to achieving a superior innovation performance. Burgelman et al. (2004) defined innovation capability as the organizational characteristics that support and facilitate innovation strategies. Neely and Hii (1998) defined innovative capacity as "the potential of a firm, a region or a nation to generate innovative outputs". Lawson and Samson (2001) defined innovation capability as "the ability to continuously transform knowledge and ideas into new products, processes and systems for the benefit of the firm and its stakeholders". Innovation capability creates value for organizations in a number of areas such as creating new product and services, being more adaptive and flexible, exploiting new ideas, being better able to learn, and enhancing competitiveness in a changing business world (Neely and Hii, 1998; Shan and Zhang, 2009; Terziovski, 2007). Innovation capability is related to a variety of factors and thus is affected by different internal and external factors (Bullinger et al. 2007; Egbetokun et al. 2007; Yeşil et al., 2012). Neely and Hi (1998) suggested three sets of factors that influence organizational innovativeness: organizational characteristics, managerial characteristics and environmental characteristics. In this study, it is argued that various important values associated with IWE of the managers affect innovation capability of the firms.

\section{Hypotheses Development}

Islamic Work Ethic, Individual and Firm Characteristics: The first question that this study tries to answer is to explore the relationship between respondent's demographic characteristics, company characteristics and IWE values. Demographic characteristics are known to have impact on various individual and organizational outcomes. For instance, Bakan et al. (2005) found that attitudes toward 
work satisfaction differ across the demographic characteristics of the respondents. Abbasi et al. (2009) noted that age has a main role in the learning process of the life. Göksu and Bilge (2010) argued that age has important impact on the peoples' decision-making. Different age groups tend to approach decision making differently and reach different decisions. Gender has also implications for decision-making. It is known that men and women tend to approach the same event differently. People tend to approach decision making depending on the societal values and gender (Göksu and Bilge, 2010). Men and women make decisions in accordance with their own specific characteristics. Marital status and educational background has also implications in the work place (Küheylan, 1995). The perception and attitudes toward organizational policies and practices may differ depending on the demographic characteristics. Demographic characteristics have also implications regarding IWE values. Several studies in the literature examined the influences of personal dispositions on the IWE values (Abbasi et al. 2009; Ali and AlQwaihan, 2008; Kumar and Rose, 2010; Yousef, 2001). People with different demographic characteristics tend to approach IWE differently. The findings of several studies support this notion. For example, Abbasi et al. (2009) found the difference towards IWE depending on demographic characteristics. They found that with the increase in age there is higher propensity toward IWE values. In terms of gender, they found that female respondents have higher propensity towards IWE values. In another study, Kumar and Rose (2010) have also looked at whether IWE values differ depending on demographic characteristics. According to the result from this study, absorption of IWE values differs across age, years of service, educational levels and position. The researchers mentioned several previous studies regarding relationship between individual dispositions and IWE values. While some studies found significant differences between IWE values and some demographic characteristic, others found insignificant differences between some demographic variable and IWE values. In this study, the relationship between individual demographic characteristics and IWE values is explored. In addition to the other studies (e.g., Kumar and Rose, 2010), current study adds another dimension to this type of research by including firm characteristics into research. Thus, this study also looks at the whether IWE values differ across the various firm characteristic. Based on the previous arguments, following hypotheses are formulated;

H1: IWE values differ across respondent's demographic characteristics

H2: IWE values differ depending on the company characteristics

Islamic Work Ethic and Innovation Capability: Current study proposes that there is a link between IWE values and innovation capability. Theoretical and empirical considerations relating to the proposed link are given below. Ethic in the workplace has several positive implications for both individual outcomes such as job satisfaction, commitment and organisational citizenship behaviour (Koonmee et al. 2009; Sabir et al. 2012; Sparrow et al. 2010) and organisational outcomes such as firm performance (Berrone et al. 2007; Donker et al. 2008; Sabir et al. 2012). Jalil et al. (2010) noted that ethical practices and implementation are very important for organisational functioning and well-being. They further argued that job satisfaction and positive personnel well-beings can be achieved in ethic-based organisations. People in these types of organizations are likely to feel more attached and responsible for the organizational success. Luthans (2002) refer to the several studies that show the positive relationship between ethic and organizational outcomes. Barutçugil (2004) argued that ethic organizations are likely to make right decisions regarding product, services, performance and performance evaluations. From these studies, it can be said that being ethical pays off for the organizations. On the other hand being unethical result in negative organizational outcomes. Organizational innovativeness is one of the most important requirements for organisations to survive in today's highly competitive business world (Calantone et al. 2002; Neely and Hii, 1998; Shan and Zhang, 2009; Terziovski, 2007; Yeşil and Kaya, 2012). Therefore, organizational success highly depends on the ability to innovate. The IWE values have the potential to improve innovation capability of the organisations (Abbasi et al. 2009; Awan and Akram, 2012; Kumar and Rose, 2010). Abbasi et al. (2009) noted that integrating IWE values into the organization help organization to better capitalise on the human resources. As suggested by Neely and Hi (1998), managerial characteristics play an important role in determining innovation capability of the organisations. IWE values of the managers encourage hard working, creativity, honesty, commitment to duty and organizations, and good human relations. Jalil et al. (2010) claimed that internalization of Islamic ethical practices strengthen certain qualities such as honesty, trust, solidarity, loyalty and flexibility. In a similar vein, Kumar and Rose (2010) mentioned several positive attitudes derived from implementing IWE such as hard work, commitment, dedication to work, work creativity, cooperation and fair compositeness in the work place. These values all together have the potential to enhance the propensity of an organization to innovate. Supporting the theoretical argument, there are some empirical findings related to the proposed relationship. For example, Kumar and Rose (2010) found that there are 
significant positive correlation between IWE values and innovation capability of the firms. In another study, IWE were found to be related to the organisational innovation (Abbasi et al. 2012). Similarly, Awan and Akram (2012) reported that that IWE has a significant positive effect on innovation capability in public sector organisations. Based on these arguments, following hypothesis is suggested;

H3: IWE values has a significant positive impact on innovation capabilities of the firms

Islamic Work Ethic and Firm Performance: One of the main questions of this study is to investigate the influence of IWE values on the firm performance. The study proposes that the implementation of IWE values affects firm performance. Embracing ethic in the organizations can create value for organizations in several areas. Mead (1998) noted that companies reflecting moral leadership tend to create positive image in the eye of public and create a positive organizational culture. Barutçugil (2004) argued that ethical companies could gain a number of advantages (e.g., efficiency, employee accountability, communication efficiency, and competitive advantages). Gooderham and Northaug (2003) argued that developing ethic codes and implementing them would serve the long-term objectives of the companies. Certo (1992) argued that the employment of ethical business practices can enhance supplier and customer relations, improve productivity, and help to avoid regulations from government agencies. Berrone et al. (2007) argued that ethics and business are not unrelated worlds and noted that acting ethically is ultimately in the company's best financial interest. Companies following ethical standards contribute to the organizational success, create wealth for stakeholders, and promote well-beings for society as whole (Barutçugil, 2004; Berrone al. 2007; Donker et al. 2008; Jalil et al. 2010; Mead, 1998). Ethic based work place generates job satisfaction, commitment and good corporate citizenship (Ali and Al-Owaihan, 2008; Jalil et al. 2010; Koonmee et al. 2009; Sabir et al. 2012; Sparrow et al. 2010). These are the fundamental elements for organizations to perform effectively. Creating an ethical climate and practicing the ethical codes is likely to create an atmosphere of prosperity, efficiency and productivity along with many other advantages. The IWE values of the managers can also have the capacity to influence organizational success. Ali (2005) noted that IWE values (hard work, effort, competition, loyalty, transparency and morally responsible conduct etc.) collectively inspire social contract and encourages a better focus on meeting organizational task and goals. Similarly, Kumar and Rose (2010) mentioned several positive attitudes resulted from practicing IWE such as hard work, commitment, dedication to work, work creativity, cooperation and fair competitiveness in the work place. These values are critical human assets that determine the efficiency, productivity and performance in the organizations. Jalil et al. (2010) claimed that work ethics differ and all of them including IWE positively affect organizational well functioning. Continuous development, increased customer satisfaction and better image of business organization can be achieved through implementation of IWE in the organizations (Jalil et al. 2010). Ali and Al-Owaihan (2008) noted that the effective implementation of IWE would result in higher performance and widespread prosperity. Supporting the argument above, many researchers assured that IWE principles has the potential to improve the quality and performance of the individuals and organizations (Ahmad, 2011; Ali and Al-Owaihan, 2008; Husin, 2012; Jalil et al. 2010; Kumar and Rose, 2010). Again supporting our argument, in an empirical study, Abbasi et al. (2012) found that IWE is positively related to firm performance. Based on these information provided above, the following hypothesis is developed;

H4: IWE values has a positive impact on the firm performance

\section{Methodology}

Sample and Data Collection: A survey method was used to collect data and to accomplish the research objectives. A questionnaire was designed based on the various related literatures. The questionnaire consisted of three parts. First part includes questions regarding respondent demographic characteristics and company characteristics. The second part measured the adaptability of the IWE values of the respondents. Third parts tried to measure the innovation capability and the implementation effects of the IWE values on the company performance. The target population for this study is the companies operating within the district of Kahramanmaras, in Turkey. Although survey questionnaire were sent to 300 companies, 96 usable replied questionnaire returned. In order to increase low response rate and bypass the inaccurate mail address, some questionnaire were dropped and picked by the researchers. All analyses were performed based on these data collected through survey by using the SPSS. Considering purposes of this study, correlation, T-test, ANOVA and regression analysis in SPSS were used. The IWE was measured using 17 items developed by Ali (1988), innovation capability was measured using five items adapted from Lin (2007) and performance was measured by using fifteen items taken and adapted 
to this study from Glaister and Buckley (1998) and Panayides (2006). All the items were rated on a fivepoint Likert-type scale ranging between degrees of strongly disagree and strongly agree.

\section{Results}

Descriptive Statistics Results: The first part of the survey gathers information about background of the respondents. The sample characteristics of the respondents are shown in Table 1. Out of 96 respondents, 84 percent were male and 16 percent were female. Respondent ages ranged from 20 to over 51 but the majority of the respondents (36.5\%) are in the age range from 41 to 50, whereas 35.4 percent of the respondents were aged between 31 to 40 years. The respondents are distributed by education level as follows: $20.8 \%$ had less than bachelor's degree; 56.2\% achieved a bachelor's degree and only $21.8 \%$ earned a master's qualification. Position levels ranged as follows: lower level: $11.5 \%$; middle level: $43.8 \%$; and higher level: $40.6 \%$. The distribution of work experience was as follows: fewer than 3 years $6.3 \%$; 46 years $31.3 \%$; $7-9$ years $27.1 \%$ and 10 years or more $34.4 \%$. Table 2 shows the Cronbach's Alpha values for three variables and summaries the scale sources. While innovation capability and IWE scales are slightly below 0.70 level, the firm performance is higher than 0.70 . These results tend to reflect the reliability of scales used in the survey.

Results regarding whether IWE values differ across the respondent's demographic characteristics and firm characteristics: In order to test $\mathrm{H} 1, \mathrm{~T}$-test and one way ANOVA accordingly were performed in order to determine whether IWE values differ across the individual and firm variables. As seen in Table 3, the results showed that absorption of IWE values do not differ across gender $(F=0.078, p>0.05)$, age ( $F=$ $1.452, \mathrm{p}>0.05)$ and years of service $(\mathrm{F}=0.479, \mathrm{p}>0.05)$. However, there was statistically meaningful differences according to educational level $(\mathrm{F}=3.130, \mathrm{p}<0.05)$ and position $(\mathrm{F}=4.775, \mathrm{p}<0.01)$ towards IWE values. These results reveal the fact that absorption of IWE values differs based on some demographic characteristics (education level and position) of the respondents, leading partially to support H1.

Table 1: Sample Demographic Characteristics

\begin{tabular}{lccllc}
\hline Variables & $\mathbf{N}$ & $\mathbf{\%}$ & Variables & $\mathbf{N}$ & $\mathbf{\%}$ \\
\hline Gender & & & Educational Level & & \\
& & & Secondary School & 8 & 8.3 \\
Female & 16 & 16 & Associate Degree & 12 & 12.5 \\
Male & 80 & 84 & Bachelor & 54 & 56.2 \\
Total & 96 & 100 & Master's & 21 & 21.8 \\
& & & PhD & 1 & 1,2 \\
Age & & & Total & 96 & 100 \\
$20-30$ & 9 & 9.4 & Position & 39 & 40. \\
$31-40$ & 34 & 35.4 & Middle Level Manager & 42 & 6 \\
$41-50$ & 35 & 36.5 & Lower Level Manager & 11 & 43.8 \\
$51>$ & 18 & 18.8 & Others & 4 & 11.5 \\
Total & 96 & 100 & Total & 96 & 4.2 \\
Years of work experience & & & & & \\
$1<$ & 1 & 1.0 & & & \\
$1-3$ & 6 & 6.3 & & & \\
$4-6$ & 30 & 31.3 & & & \\
$7-9$ & 26 & 27.1 & & & \\
$10>$ & 33 & 34.4 & & & \\
Total & 96 & 100 & & & \\
\hline
\end{tabular}

Table 2: Cronbach Alpha Values and Source of Scales

Notes: LRF - Likert Response Format (Five point: 1=strongly disagree to 5=strongly agree)

\begin{tabular}{lllll}
\hline Concepts & $\begin{array}{l}\text { Number of } \\
\text { Items }\end{array}$ & $\begin{array}{l}\text { Scale } \\
\text { Format }\end{array}$ & $\begin{array}{l}\text { Cronbach's } \\
\text { Alpha }\end{array}$ & Scale Sources \\
\hline Islamic Work Ethics & 16 & LRF & 0.637 & Ali (1988) \\
Innovation Capability & 5 & LRF & 0.665 & $\begin{array}{l}\text { Lin (2007) } \\
\text { Glaister and Buckley (1998), } \\
\text { Firm Performance }\end{array}$ \\
& 14 & LRF & 0.825 & \\
\hline
\end{tabular}


Table 3: Result of One-Way ANOVA test of IWE with Individual Variables

\begin{tabular}{|c|c|c|c|c|c|}
\hline Variables & $N$ & Mean & $S D$ & F-statistic & $p$ \\
\hline \multicolumn{6}{|l|}{ Gender } \\
\hline Female & 16 & 4.43 & 0.212 & \multirow{2}{*}{0.078} & \multirow{2}{*}{0.506} \\
\hline Male & 80 & 4.47 & 0.203 & & \\
\hline \multicolumn{6}{|l|}{ Age } \\
\hline $20-30$ & 9 & 4.46 & 0.920 & \multirow{4}{*}{1.452} & \multirow{4}{*}{0.233} \\
\hline $31-40$ & 33 & 4.42 & 0.215 & & \\
\hline $41-50$ & 35 & 4.48 & 0.201 & & \\
\hline $51>$ & 18 & 4.54 & 0.220 & & \\
\hline \multicolumn{6}{|l|}{ Educational Level } \\
\hline Secondary School & 8 & 4.64 & 0.176 & \multirow{5}{*}{3.130} & \multirow{5}{*}{0.019} \\
\hline Önlisans & 12 & 4.49 & 0.218 & & \\
\hline Bachelor & 54 & 4.45 & 0.187 & & \\
\hline Master's & 21 & 4.46 & 0.212 & & \\
\hline $\mathrm{PhD}$ & 1 & 4.00 & - & & \\
\hline \multicolumn{6}{|l|}{ Years of service } \\
\hline $1<$ & 1 & 4.53 & - & \multirow{5}{*}{0.479} & \multirow{5}{*}{0.751} \\
\hline $1-3$ & 6 & 4.49 & 0.960 & & \\
\hline $4-6$ & 29 & 4.43 & 0.208 & & \\
\hline $7-9$ & 26 & 4.50 & 0.213 & & \\
\hline $10>$ & 32 & 4.47 & 0.184 & & \\
\hline \multicolumn{6}{|l|}{ Position } \\
\hline Upper Level Manager & 39 & 4,53 & 0.200 & \multirow{4}{*}{4.775} & \multirow{4}{*}{0.004} \\
\hline Middle Level Manager & 42 & 4,46 & 0.204 & & \\
\hline Lower Level Manager & 11 & 4,28 & 0.131 & & \\
\hline Others & 4 & 4,45 & 0.088 & & \\
\hline
\end{tabular}

In order to test $\mathrm{H} 2$, one way ANOVA was run again and the results are displayed in Table 4. The results of the ANOVA test revealed that there were no significant differences across structure of management ( $F=$ $0.356, p>0.05)$ and age of firm ( $F=1.831, p>0.05)$ on IWE. Therefore, it can be said that IWE values does not differ according to these firm characteristics. However, the results indicate that the absorption of IWE differs based on trade name $(F=10.625, p<0.01)$, number of employees $(F=3.634, p<0.01)$ and industry $(\mathrm{F}=7.345, \mathrm{p}<0.01)$. This result shows some support for $\mathrm{H} 2$ representing the notion that IWE values differ across the firm characteristics.

Table 4: Results of one-Way ANOVA Test of IWE with Firm Variables

\begin{tabular}{|c|c|c|c|c|c|}
\hline Variables & $N$ & Mean & $S D$ & F-statistic & $p$ \\
\hline \multicolumn{6}{|l|}{ Trade Name } \\
\hline Stock Company & 29 & 4.44 & 0.178 & \multirow{4}{*}{10.625} & \multirow{4}{*}{0.000} \\
\hline Limited Company & 37 & 4.38 & 0.208 & & \\
\hline Unlimited Company & 20 & 4.66 & 0.155 & & \\
\hline Others & 10 & 4.47 & 0.205 & & \\
\hline \multicolumn{6}{|l|}{ Management Structure } \\
\hline Family Members & 25 & 4.45 & 0.210 & \multirow{3}{*}{0.356} & \multirow{3}{*}{0.701} \\
\hline Partners Outside The Family & 22 & 4.50 & 0.221 & & \\
\hline Professional Managers & 49 & 4.46 & 0.199 & & \\
\hline \multicolumn{6}{|l|}{ Firm Age } \\
\hline $1-5$ & 1 & 4.53 & - & \multirow{5}{*}{1.831} & \multirow{5}{*}{0.130} \\
\hline $6-10$ & 20 & 4.35 & 0.214 & & \\
\hline $11-15$ & 27 & 4.52 & 0.194 & & \\
\hline $16-20$ & 31 & 4.49 & 0.207 & & \\
\hline $21>$ & 18 & 4.46 & 0.181 & & \\
\hline
\end{tabular}




\begin{tabular}{|c|c|c|c|c|c|}
\hline \multicolumn{6}{|c|}{ Employee Number } \\
\hline $1-49$ & 21 & 4.33 & 0.189 & \multirow{6}{*}{3.604} & \multirow{6}{*}{0.005} \\
\hline $50-99$ & 25 & 4.55 & 0.159 & & \\
\hline $100-149$ & 27 & 4.52 & 0.258 & & \\
\hline $150-249$ & 12 & 4.43 & 0.131 & & \\
\hline $250-499$ & 7 & 4.49 & 0.121 & & \\
\hline $500>$ & 4 & 4.48 & 0.088 & & \\
\hline \multicolumn{6}{|l|}{ Industry } \\
\hline Textile & 28 & 4.44 & 0.172 & \multirow{4}{*}{7.345} & \multirow{4}{*}{0.000} \\
\hline Food & 34 & 4.38 & 0.211 & & \\
\hline Steel Goods & 21 & 4.62 & 0.176 & & \\
\hline Others & 13 & 4.52 & 0.148 & & \\
\hline
\end{tabular}

Results relating to the link between IWE values and innovation capability and company performance: In order to test $\mathrm{H} 3$ and $\mathrm{H} 4$, both correlation and regression analysis were used. Table 5 contains the mean values, standard deviations, and correlations for all of the variables.

Table 5: Means, Standard Deviations and Correlations of the Main Research Variables

\begin{tabular}{lllccc}
\hline Variables & Mean & SD & IWE & $\begin{array}{l}\text { Innovation } \\
\text { Capability }\end{array}$ & $\begin{array}{l}\text { Firm } \\
\text { Performance }\end{array}$ \\
\hline IWE & 4.47 & 0.204 & 1.00 & & \\
Innovation Capability & 3.99 & 0.272 & $0.380^{* *}$ & 1.00 & $0.502^{* *}$ \\
Firm Performance & 4.41 & 0.297 & $0.419^{* *}$ & 1.00 \\
\hline
\end{tabular}

** Correlation is significant at the 0.01 level (2-tailed).

The results of correlation analysis show that there is a significant positive relationships between IWE and innovation capability $(r=0.380 \mathrm{p}<.01, n=96)$ and firm performance $(r=0.419, \mathrm{p}<.01 n=96)$. This result reflects the positive correlations among the IWE values and innovation capability and firm performance. A hierarchical regression analysis was also conducted to test the hypotheses (H3 and H4). This analysis aims to identify the relationship among IWE, innovation capability and firm performance. The hierarchical regression was performed in two steps. Control variables were entered during the first step, and the independent variable was added in the second step. The results are shown in Table 6 and 7 respectively. The results in Table 6 reveal that all the variables including control variables accounted for $11 \%$ of the variance in innovation capability $\left(\Delta R^{2}=.117, \mathrm{~F}=3.991, \mathrm{p}<.00\right)$. The results in Table 6 reflect that IWE (beta=.380, p<.00) is positively related to innovation capability. The results in Table 7 show that all the variables including control variables accounted for $14 \%$ of the variance in firm performance $\left(\Delta R^{2}=.142, \mathrm{~F}=4.689, \mathrm{p}<.00\right)$. The results in Table 7 reveal that IWE (beta=.429, $\left.\mathrm{p}<.00\right)$ has a positive effect on firm performance. The overall results reflect that IWE is positively related to innovation capability in Table 6, and firm performance in Table 7. These results support H3 and H4 and mean that IWE has positive implication for both innovation capability and firm performance.

Table 6: Hierarchical regression analysis of IWE on innovation capability Dependent Variable: Innovation Capability

\begin{tabular}{|c|c|c|c|c|}
\hline \multirow[b]{2}{*}{ Independent Variables } & \multicolumn{2}{|c|}{ Step 1} & \multicolumn{2}{|l|}{ Step 2} \\
\hline & $\beta$ & $t$ & $\beta$ & $t$ \\
\hline Age of the firm & -.053 & -.460 & -.058 & -.541 \\
\hline Number of employees & .184 & 1.560 & .108 & .955 \\
\hline Sector & .032 & .296 & -.084 & -.781 \\
\hline$I W E$ & & & $.380^{* *}$ & 3.626 \\
\hline$R^{2}$ & .028 & & .157 & \\
\hline$\Delta R^{2}$ & -.006 & & .117 & \\
\hline $\mathrm{F}$ & .824 & & $3.991^{* *}$ & \\
\hline
\end{tabular}


Table 7: Hierarchical regression analysis of IWE on firm performance Dependent Variable: Firm Performance

\begin{tabular}{lllll}
\hline & \multicolumn{3}{c}{ Step 1 } & \multicolumn{1}{c}{ Step 2 } \\
\hline Independent Variables & $\boldsymbol{\beta}$ & $\boldsymbol{t}$ & $\boldsymbol{\beta}$ & $\boldsymbol{t}$ \\
\hline Age of the firm & -.048 & -.412 & -.052 & -.483 \\
Number of employees & -.033 & -.274 & -.122 & -1.087 \\
Sector & .104 & .939 & -.025 & -.237 \\
& & & & 4.127 \\
$I W E$ & & & $.429 * *$ & .181 \\
$R^{2}$ & & & .142 & \\
$\Delta R^{2}$ & .017 & & $4.689 * *$ & \\
$\mathrm{~F}$ & -.018 & & & \\
\hline
\end{tabular}

$\mathrm{N}=96^{* * \mathrm{p}}<.00$

\section{Conclusion}

This study is conducted on the firms operating in Kahramanmaraş in Turkey and aimed to reveal whether IWE values differ across the demographic characteristics of the respondents and firm characteristic. The study also investigated the role of IWE values on firm innovation capability and performance. The findings from the research reveal the fact that absorption of the IWE values differ across some demographic (education level and position) and firm variables (trade name, employee number and industry type). These hypotheses, H1 (IWE values differ across respondent's demographic characteristics) and H2 (IWE values differ depending on the company characteristics) are partially supported. These findings are parallel to the previous studies. Previous studies found that there are some differences toward IWE values depending on demographic characteristics (Abbasi et al., 2009; Kumar and Rose, 2010). Past studies also found that there are some differences regarding absorption of IWE values based on firm characteristics (Ali and Al-Qwaihan, 2008). Regarding the insignificant relationship between demographic variables and absorption of IWE values is also consistent with some previous studies (e.g., Yousef, 2001; Yunus et al. 2011). The most striking result emerged from this research is that IWE values positively affect innovation capability of the participating firms. Therefore, the finding gives full support for H3 (IWE values has significant positive impact on innovation capabilities of the firms). Previous studies also support the findings of this study regarding the relationship between IWE values and firm innovation capability (e.g., Abbasi et al. 2012; Awan and Akram, 2012; Kumar and Rose, 2010). This finding is also consistent with theoretical arguments in the related literatures (Barutçugil, 2004; Jalil et al. 2010; Kumar and Rose, 2010; Luthans, 2002), and provides insight into understanding the determinants of innovation capability in the firms. Several study showed the important role of innovation capability for the innovation and firm performance (e.g., Calantone et al. 2002; Han et al. 1998; Panayides, 2006; Peeters and Potterie, 2004). As this study found, managerial adoption of IWE values in the workplace is likely to increase the propensity of the firms to innovate. Firms need to pay attention to understanding, implementation and monitoring of IWE in the workplace.

Another important finding from this study is that IWE values are positively related to firm performance. This result provides support for H4 (IWE values has a positive impact on the firm performance). The finding supports the theoretical arguments in the literature (Ali, 2005; Gooderham and Northaug, 2003; Kumar and Rose, 2010; Yunus et al. 2011) as well as empirical studies (Abbasi et al. 2012) regarding such link. Similar to our study, Abbasi et al. (2012) found that IWE is related to firm performance. Yunus et al. (2011) argued that employees holding IWE values do their best to ensure that organisational goals are met and consequently better performance outcomes are achieved. Similarly Berrone et al. (2007) claimed that acting ethically in the workplace would be reflected in the performance outcomes. These explanations indeed explain the positive relationship found between IWE and firm performance in this study. All together, the arguments and empirical findings suggest that organisations need to embrace the ethical values and act upon them. Then, organisations are easily able to accomplish their goals and realise better performance outcomes. The result from this study indicates the absorption of IWE values by the managers of the participating firms in Kahramanmaraş in Turkey. Our result supports the conclusion raised by Arslan (2000) that religious motives affect business life in several ways in Turkey. This result seems to be contrary to the findings of Uygur (2009) in which Islamic business principles were not a significant factor on business people. Uygur (2009) looked at the Islamic principles and its influence 
various aspect of life including different aspect of business life on business people. Whereas, the current study specifically looked at the IWE and conducted in Kahramanmaraş where most business people are conscious about religion and its practice. Moreover, our finding indirectly supports the previous empirical researches that found the positive effect of IWE values on job satisfaction (Haroon et al. 2012; Rokhman, 2010), commitment (Rokhman, 2010; Salem and Agil, 2012; Yousef, 2001), learning (Abbasi et al. 2012), employee performance (Sabir et al. 2012) and organisational citizenship behaviour (Alhyasat, 2012). These studies as well as the current study show that IWE is an important construct as it relates to several individual and organisational outcomes.

Furthermore, the results from this research also give supports to the work ethic related empirical studies (Berrone et al. 2007; Donker et al. 2008; Koonmee et al. 2009; Sabir et al. 2012; Sparrow et al. 2010) in a way that IWE has organisational wide implications such as innovation capability and performance. Considering the fact that IWE and Protestant work ethic share similar characteristics (Arslan, 2000), our findings also give support the other work ethic related studies conducted in Western countries where protestant work ethic is practiced. In addition, a recent interesting survey (Deloitte, 2010) reveals that there has been decreasing value of ethics in the workplace. Undertaking a study related to work ethic is timely and has something to say to the organisation worldwide that ethic in the workplace is important and no one can afford to avoid it whether work ethic is Islamic or other religions based. Some limitations of this study need to be taken into account when evaluating the findings. The fact that the findings are drawn from the firms operating within district of Kahramanmaras in Turkey constitutes barriers toward the transferability of the current study findings. Therefore, the findings of this study should be approached with caution. For this reason, it is highly advisable to further conduct researches in this area in various contexts. It is also important to bear in mind that the data for this research is collected from the managers and thus limited the strength and generalizability of the findings. Thus, further research should include employees in the firms to better understand the implications of IWE in the workplace. As findings of this study as well as the previous studies indicate, IWE is an important concept for both individual and organisations, thus its dynamics and implications in the workplace need to be further explored. IWE and performance link or IWE and innovation capability link can be explored through some mediators such as commitment and organisational citizenship (e.g., Chun et al., 2011). Researchers took some measures to tackle common-method biases inherent in this type of research. Following Podsakoff et al. (2003), researchers ensured the respondents with information in the front-page of the questionnaire regarding the confidentiality of their individual responses. In order reduce respondents' concern about being evaluated; we also assured the participants that there was no right or wrong answers to questions in the questionnaire.

\section{References}

Abbasi, A. S. Ghulam, M. M. \& Muzammil, H. (2012). Islamic work ethics: How they affect organizational learning, innovation and performance, Actual Problems of Economics, Accepted for Publication in December 2012. Retrieved from http://www.ciitlahore.edu.pk/Papers/Abstracts/5398588666007891963308.pdf

Abbasi, A. S., Rehman, K. \& Afsar, S. (2009). Propensities of Tajik, Uzbek and Russians towards Islamic work ethics. Journal of Qafqaz University, 28(2).

Ahmad, M. S. (2011). Work ethics: An Islamic prospective. International Journal of Human Science, 8(1), 851-859.

Alhyasat, K. M. K. (2012). The role of Islamic work ethics in developing organizational citizenship behaviour at the Jordanian Press Foundations. Journal of Islamic Marketing, 3(2), 39-154.

Ali, A. (1988). Scaling an Islamic work ethic. Journal of Social Psychology, 128(5), 575-83.

Ali, J. A. (2005). Islamic perspectives on management and organization. UK: Edward Elgar Publishing.

Ali, A. J. \& Al-Owaihan, A. (2008). Islamic work ethic: a critical review. Cross Cultural Management: An International Journal, 15(1), 5-19.

Arnold, D. G., Audi, R. \& Zwolinski, M. (2010). Recent work in ethical theory and its implications for business ethics. Business Ethics Quarterly, 20, 559-581.

Arslan, M. (2000). A cross-cultural comparison of British and Turkish managers in term of Protestant work ethic characteristics. Business Ethics: A European Review, 9(1), 13-19.

Awan, K. Z. \& Akram, M. (2012). The Relationship between Islamic Work Ethics and Innovation Capability and Knowledge Sharing Plays Moderation Role. International Journal of Economics and Management Sciences, 1(8), 34-48. 
Bakan, İ., Güven, M. \& Yeşil, S. (2005). Çalışanların iş ve ücret tatmini boyutlarıyla demografik özellikler arasındaki iliş̧kiler: bir alan çalışması. Celal Bayar Üniversitesi IIIBF Dergisi, 12(1), 127-53.

Barutçugil, İ. (2004). Stratejik insan kaynakları yönetimi, Birinci Baskı. İstanbul: Kariyer Yayınları.

Bassiouni, M. C. (1993). Business ethics in Islam. In: Paul M. Minus, editors. In The Ethics of Business in a Global Economy. Dordrecht: Kluwer Academic, 117-22.

Berrone, P., Surroca, J. \& Tribo, J. A. (2007). Corporate ethical identity as determinant of firm performance: a test of the mediating role of stakeholder satisfaction. Journal of Business Ethics, 76 (1), 35-53.

Bullinger, H. J., Bannert, M. \& Brunswicker, S. (2007). Managing innovation capability in SMEs. Tech Monitor, Special Feature: Innovation \& KM by SMEs, May-June, 17-27.

Burgelman, R. A., Christensen, C. M. \& Wheelwright, S. C. (2004). Strategic management of technology and innovation. Boston: McGraw-Hill.

Calantone, R. J., Cavusgil, S. T. \& Zhao, Y. (2002). Tacit knowledge transfer and firm innovation capability. Journal of Business Industrial Marketing, 18(1), 6-21.

Certo, S. C. (1992). Modern management: quality, ethics and global environment. Boston, MA.

Chun, J. S., Shin, Y., Choi, J. N. \& Kim, M. S. (2011). How Does Corporate Ethics Contribute to Firm Financial Performance? The Mediating Role of Collective Organizational Commitment and Organizational Citizenship Behavior. Journal of Management, To be published.

Deloiite, I. (2010). Trust in the workplace: Ethic and workplace survey. Retrieved from http://www.deloitte.com/view/en_US/us/About/Ethicsindependence/8aa3cb51ed812210VgnVCM100000ba42f00aRCRD.htm

Donker, H., Poff, D. \& Zahir, S. (2008). Corporate Values, Codes of Ethics, and Firm Performance: A Look at the Canadian Context. Journal of Business Ethics, 82, 527-537.

Drucker, P. F. (1954). The Practice of Management. New York: Harper and Row Publishers

Egbetokun, A. A., Siyanbola, W. O. \& Adeniyi, A. A. (2007). Assessment of innovation capability in the cable and wire manufacturing industry in Nigeria: A case study approach. Retrieved from http://www.merit.unu.edu/MEIDE/papers/2007/EGBETOKUN_SIYANBOLA_ADENIYIAssessme nt\%20of\%2innovation\%20 capability...cable\%20\&\%20wire\%20manufacturing\%20industry.pdf

Glaister, K. W. \& Buckley, P. J. (1998). Measures of performance in UK Alliance Formation. Organisation Studies, 19(1), 89-118.

Gooderham, P. N. \& Northaug, O. (2003). International management: cross boundary challenges. Oxford: Blackwell Publishing Ltd.

Göksu, N. \& Bilge, A. (2010). Tüketici Davranışları, Gazi Kitabevi.

Günday G., Ulusoy, G., Kılıç, K. \& Alpkan, L. (2009). Effects of Innovation Types on Firm Performance. International Journal of Production Economics, 133(2), 662-676.

Han, J. K., Kim, N. \& Srivastava, R. J. (1998). Market Orientation and Organization performance: is Innovation a Missing Link? Journal of Marketing, 62(4), 30-45.

Haroon, M., Zaman, H. M. F. \& Rehman, W. (2012). The Relationship between Islamic Work Ethics and Job Satisfaction in Healthcare sector of Pakistan. International Journal of Contemporary Business Studies, 3(5), 6-12.

Hodgetts, R. M. \& Luthan, F. (2000). International Management. New York: The McGraw-Hill.

Husin, W. N. W. (2012). Work Ethics from the Islamic Perspective in Malaysia. European Journal of Social Sciences, 29(1), 51-60.

Ip, P. K. (2010). Business ethics and well-beings of nations-is there a connection. Journal of Business Ethics, (95), 97-110.

Jalil, A., Azam, F. \& Rahman, M. K. (2010). Implementation mechanism of ethics in business organizations. International Business Research, 3(4), 45-151.

Knight, G. A. \& Cavusgil, S. T. (2004). Innovation, organizational capabilities, and the born-global firm. Journal of International Business Studies, 35, 124-141.

Koonmee, K., SinghapakdEgi, A., Virakul, B. \& Lee, D. J. (2009). Ethics institutionalization, quality of work life, and employee job-related outcomes: A survey of human resource managers in Thailand. Journal of Business Research, 2(1).

Kumar, N. R. \& Rose, R. C. (2010). Examining the link between Islamic work ethic and innovation capability. Journal of Management Development, 29(1), 79-93.

Küheylan, E. (1995). Satın Alma Karar Sürecinde Aile Bireylerinin Rolü ve Aile Yapısının Satın Alma Kararlarına Etkisi.

Kreitner, R. (1995). Management. 6th ed. Boston: Houghton Mifflin. 
Lawson, B. \& Samson, D. (2001). Developing Innovation Capability in Organisations: A Dynamic Capabilities Approach. International Journal of Innovation Management, 5(3), 377-400.

Lin, H. F. (2007). Knowledge sharing and firm innovation capability: An empirical study. International Journal of Manpower, 28(3/4), 315-332.

Luthans, F. (2002). Organizational behaviour. Boston: McGraw-Hill.

Maddux, R. B., Maddux, D. \& Sanders, M. (1989). Ethics in business: a guide for managers. Axzo Press: United States of America. Retrieved from http://www.axzopress.com/downloads/pdf/0931961696pv.pdf

Mead, R. (1998). International management: cross-cultural dimensions. Second Eds. Oxford: Blackwell Publishers.

Mendenhall, M., Punnett, B. J. \& Ricks, D. (1995). Global management. Oxford, K: Blackwell.

Mohamed, N., Karim, N. S. A. \& Hussein, R. (2010). Linking Islamic Work Ethic to Computer Use Ethics, Job Satisfaction and Organisational Commitment in Malaysia. Journal of Business Systems, Governance and Ethics, 5(1), 13-23.

Mortensen, R. A., Smith, J. E. \& Cavanagh, G. F. (1989). The importance of ethics to job performance: An empirical investigation of managers' perceptions. Journal of Business Ethics, 8(4), 255.

Neely, A. \& Hii, J. (1998). Innovation And Business Performance: A Literature Review, The Judge Institute of Management Studies University of Cambridge, Retrieved from http://ecsocman.hse.ru/data/696/521/1221/litreview_innov1.pdf

Oslo, M. (2005). The Measurement of scientific and technological activities: guidelines for collecting and interpreting innovation data, 3rd ed. Organisation for economic co-operation and development statistical office of the European communities.

Othman, A. S. S., Rahman, N. M. A., Malek, Z. A. \& Osman, A. R. (2004). Organizational Commitment And Work Ethics: An Empirical Assessment in A Malaysian Context. Retrieved from http://faculty.kfupm.edu.sa/coe/sadiq/proceedings/SCAC2004/30.ASC041.EN.Othman.Organiza tional 20Commitment\%20and\%20Work\%20E\%20_1_.pdf

Özgen, M. (1998). Gazetecinin etik kimliği, Tezler Dizisi, Istanbul: Türkiye Gazeteciler Cemiyeti Yayınları. 19-40.

Panayides, P. (2006). Enhancing innovation capability through relationship management and implications for performance. European Journal of Innovation Management, 9(4), 466-483.

Parker. B. (1998). Globalization and Business Practice. London: Sage Pub.

Peeters, C. \& Potterie, B. P. (2004). Innovation Capabilities and Firm Labor Productivity, Centre Emile Bernheim Research Institute in Management Sciences. Retrieved from https://dipot.ulb.ac.be/dspace/bitstream/2013/9079/1/cp-0021.pdf

Porter, G. (2010). Work ethic and ethical work: distortions in the American dream. Journal of Business Ethics, 96, 535-50.

Podsakoff, P. M., MacKenzie, S. B., Lee, J. \& Podsakoff, N. P. (2003). Common method biases in behavioral research: a critical review of the literature and recommended remedies. Journal of Applied Psychology, 88, 879-903.

Rahman, N. M., Muhamad, N. \& Othman, A. S. (2006). The Relationship between Islamic Work Ethics and Organizational Commitment: A Case Analysis. Malaysian Management Review, 41(1).

Rice, G. (1999). Islamic work ethic and the implication for the business. Journal of Business Ethic, 18, 345358.

Rokhman, W. (2010). The Effect of Islamic Work Ethics on Work Outcomes. Electronic Journal of Business Ethics and Organization Studies, 15(1), 21-27.

Quddus, M., Bailey, III. H. \& White, L. R. (2009). Business ethics: perspectives from Judaic, Christian, and Islamic scriptures. Journal of Management Spirituality Religion, 6(4), 323-34.

Sabir, M. S., Iqbal, J. J., Rehman, K. U., Shah, K. A. \& Yameen, M. (2012). Impact Of Corporate Ethical Values On Ethical leadership And Employee Performance. International Journal of Business and Social Science, 3(2), 163-171.

Salem, Z. O. \& Agil, S. O. S. (2012). The Effects of Islamic Management Ethics on Organizational Commitment of Employees in Libyan Public Banks. Australian Journal of Basic and Applied Sciences, 6(7), 260-270

Shan, W. \& Zhang, Q. (2009). Extension theory and its application in evaluation of independent innovation capability. Kybernetes, 38(3/4), 457-67.

Sparrow, P. R., Chadrakumara, A. \& Perera, N. (2010). Impact of work values and ethics on citizenship and task performance in local and foreign invested firms: A test in a developing country context. 11th 
International Human Resource Management Conference (1-25). Birmingham, UK: Aston Business School.

Terziovski, M. (2007). Building innovation capability in organizations - an international cross-case perspective. Imperial College Press.

Uygur, S. (2009). The Islamic Work Ethic and the Emergence of Turkish SME Owner-Managers. Journal of Business Ethics, 88, 211-225.

Van-de, V. A. H. (1986). Central problems in the management of innovation. Management Science, 32, 509607.

Wilson, R. (2006). Islam and business. Thunderbird International Business Review, 48(19), 09.

Yeşil, S. \& Kaya, A. (2012). Exploring the link between innovation capability and financial performance. Working Paper.

Yeşil, S., Koska, A. \& Büyükbeşe, T. (2012). Knowledge Sharing Process, Innovation Capability and Innovation Performance: An Empirical Study, $2^{\text {nd }}$ International Conference on Leadership, Technology and Innovation Management, Istanbul.

Yousef, D. (2001). Islamic work ethic; a moderator between organizational commitment and job satisfaction in a cross-cultural context. Personnel Review, 30, 52-69.

Yunus, O. M., Rahim, A. R. A., Shabuddin, A. B. \& Mazlan, M. (2011). Work Ethic Of Malaysian Civil Servants, 2nd International conference on business and economic (2nd ICBER 2011) Proceeding. 